\title{
Dowex 50W: Mild Efficient Reusable Heterogeneous Catalyst for Synthesis of Quinoxaline Derivatives in Aqueous Medium
}

\author{
ARUP DATTA ${ }^{1}$ and SAMIRAN HALDER ${ }^{2 *}$ \\ ${ }^{1}$ Department of Chemistry, Shibpur Dinobundhoo Institution (College), 412/1 G.T Road (South), \\ Shibpur, Howrah, India. \\ 2Department of Chemistry, Charuchandra College, 22, Lake Road, Kolkata-700029, India. \\ ${ }^{*}$ Corresponding author E-mail: samiran14cd@gmail.com \\ http://dx.doi.org/10.13005/ojc/360629
}

(Received: September 21, 2020; Accepted: November 02, 2020)

\section{ABSTRACT}

An efficient, simple and eco-friendly procedure is reported in presence of heterogeneous Dowex $50 \mathrm{~W}$ catalyst in aqueous medium under refluxing condition to produce quinoxaline derivatives. Catalyst has participated in condensation reaction between 1,2-diamines and various aromatic 1,2-diketones smoothly with excellent yield of the products in short reaction times. Dowex 50W was used more than five times in this reaction separately and showed an excellent recyclability throughout the reaction.<smiles>[R]c1ccc(N)c(N)c1</smiles><smiles>[R]c1ccc2nc(Br)c(Br)nc2c1</smiles>
3

Keywords: Diamines, Quinoxaline Derivatives, Aqueous medium, Heterogeneous catalyst, Dowex 50W.

\section{INTRODUCTION}

In past few years, the quinoxaline derivatives get immense interest in medicinal chemistry as useful intermediates. ${ }^{1,2}$ Six membered 1,4-nitrogens containing heterocycles quinoxaline has tremendous biological activity and employed in the following diseases such as antibacterial, ${ }^{3 a}$ anti-protozoal, ${ }^{3 \mathrm{~b}}$ anti-inflammatory, ${ }^{3 \mathrm{c}}$ anti-viral, ${ }^{3 \mathrm{~d}}$ anti-cancer, ${ }^{3 e}$ antidepressant, ${ }^{3 f}$ kinase inhibitors ${ }^{3 g, h}$ and as anti-HIV. ${ }^{3 \mathrm{j}}$ In an agricultural field, these derivatives are used extensively as herbicides, fungicides and insecticides. ${ }^{4}$ Dye preparation, ${ }^{5}$ preparation of the organic semi conductors, ${ }^{6}$ manufacture of electronic substances, ${ }^{7}$ chemically controllable switch preparation, ${ }^{8}$ anion receptor for the formation of building block $^{9}$ are the valuable another practical aspects of this derivatives are reported. Different antibiotics like levomycin, echinomycin and actinoleutin where the quinoxaline derivatives present as a core moiety. It inhibits the development of gram positive bacteria and used against different transplantable tumors. ${ }^{10}$

This is an Open Access article licensed under a Creative Commons license: Attribution 4.0 International (CC- BY). Published by Oriental Scientific Publishing Company @ 2018

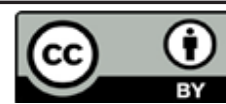


Various methods are available for the formation of these derivatives. The conventional protocol is the condensation between orthophenylenediamine and 1,2-dicabonyl system under refluxing methanol in $\mathrm{AcOH} .{ }^{11}$ Later, many advanced methodology were found to synthesize these derivatives using oxidative coupling with two different catalyst at a time ${ }^{12}$ in solid phase synthesis ${ }^{13}$ and microwave irradiation. ${ }^{14}$ The following catalysts $\mathrm{MnO}_{2},{ }^{15}$ zeolites, ${ }^{16} \mathrm{CAN},{ }^{17}$ MontmorilloniteK-10, ${ }^{18}$ ionic liquid, ${ }^{19} \mathrm{SiO}_{2} \mathrm{H}_{2} \mathrm{SO}_{4},{ }^{20}$ Nickel-nanoparticles, ${ }^{21}$ gallium(III)triflate, ${ }^{22} \mathrm{Pd}(\mathrm{OAc})_{2},{ }^{23} \mathrm{Al}_{2} \mathrm{O}_{3},{ }^{24}$ were used to prepare these derivatives. Other methods are also helpful like coupling between an epoxides and $o$-phenylenediamines followed by oxidation. ${ }^{25}$ Reaction between aromatic amino oximes and 1,2dicarbonyl compounds ${ }^{26}$ and oxidation of $\alpha$-hydroxyl ketones known as a tandem method $^{27}$ is used to design these derivatives. Acetonitrile, ${ }^{28}$ and other organic solvents were continuously used to generate a good yield of the products because of their greater solvation properties of organic substrates. Recently, some methods were reported for the development of the derivatives using catalysts such as $\mathrm{AcOH}$ at $130^{\circ} \mathrm{C}$ and $\mathrm{DMSO}^{29}$ Beside this, solvent free technique was applied to generate a good yield of the quinoxaline derivatives. Not only ultrasound, ${ }^{30}$ microwave irradiation ${ }^{24,31}$ and room temperature ${ }^{32}$ processes were also applied to prepare the quinoxaline derivatives with good yields.

Solid acid catalyst in organic transformation always plays a vital role rather than hazardous inorganic catalyst. Safe and simplicity of the process, minimized plant corrosion and environmentally benign waste disposal procedures are main advantages associated with solid heterogeneous acid catalyst. ${ }^{33}$ Researchers are constantly searching to develop such type of green catalyst that can be replaced inorganic acid easily in methodological reaction to develop a good yield of the product.

\section{RESULTS AND DISCUSSIONS}

Dowex $50 \mathrm{~W}$ is an environmentally friendly and cheap catalyst has been receiving striking importance in synthetic organic chemistry. ${ }^{34 a}$ It is a cation exchange sulphonic acid based resin produces $\mathrm{H}^{+}$ion in aqueous medium easily. This catalyst was used previously in aqueous medium to synthesize 2-aryl-1H-benzimidazole ${ }^{34 \mathrm{~b}}$ and 2-substituted benzothiazole derivatives with excellent yields in a short reaction time. ${ }^{34 c}$

Initially, we had started first the reaction between o-phenylenediamines 1a with benzil $2 a$ for the synthesis of 2,3-diphenylquinoxaline (3a, Scheme 1) under different refluxing conditions to investigate the catalyst loading and solvent effect.

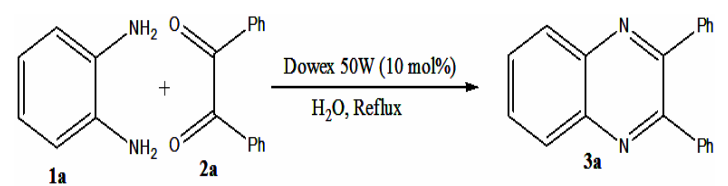

Scheme 1. Synthesis of quinoxaline derivatives by Dowex $50 W$ in $\mathrm{H}_{2} \mathrm{O}$

Our target was to design this synthesis in environmentally friendly condition and for this purpose we applied water as a solvent in this reaction. Water always acts as an environmentally benign solvent because it possesses the following advantages; such as nonflammable, readily available in huge quantities, no carcinogenic effect and very secure to operate. ${ }^{34 a}$ So, to investigate a new synthetic green methodology, we have reported an effective and simplest condensation method between 1,2dicarbonyl compound and ortho-phenylenediamine in presence of heterogeneous catalyst Dowex $50 \mathrm{~W}$ under refluxing condition to prepare quinoxaline derivatives. In order to investigate the reaction conditions such as mol\% of the catalyst and choice of solvent with respect to \%yields, we have used benzil $(1 \mathrm{mmol})$ and ortho-phenylenediamine $(1.2 \mathrm{mmol})$ as substrates in different conditions.

A non catalytic reaction was performed first between ortho-phenylenediamine and benzil in water under refluxing condition for 110 min no quinoxaline derivative was observed by TLC experiment, so acid catalyst was essential to generate the quinoxaline derivatives (Entry 1, Table 1). Step by step increasing $\mathrm{mol} \%$ of the catalyst, increases the \%yield of the products gradually and to complete the reaction $10 \mathrm{~mol} \%$ of the catalyst was required under this reaction conditions that has been proved previous published papers. ${ }^{34}$ More than $10 \mathrm{~mol} \%$ of the catalyst that means 20 and $30 \mathrm{~mol} \%$ of the catalyst was not related to improve the product. Thereafter we have examined the reaction in presence of polar protic and aprotic solvents separately. Without solvent, poor yield of quinoxaline derivative was detected (Entry 14, Table 1). Almost, all the solvents gave moderate yields except water, which afforded $88 \%$ yield (Entry 3 , Table 1 ). Even if $1: 1$ aqueous alcoholic solvent is employed, the yield was only $75 \%$ (Entry 10, Table 1). So, by combining the effect of catalyst and solvent, we can conclude that Dowex 50W catalyst in $10 \mathrm{~mol} \%$ was appropriate in aqueous medium to generate an excellent yield of the quinoxaline derivatives. 
Table 1: Effect of catalyst and solvent for the formation of quinoxaline derivatives

\begin{tabular}{|c|c|c|c|c|c|}
\hline Entry & Dowex 50W (mol\%) & ${ }^{\mathrm{a} C o n d i t i o n s}$ & Solvent (5 mL) & Time $(\min )$ & ${ }^{b}$ Yield (\%) \\
\hline 1 & NIL & Oil bath, Reflux & water & 110 & 0 \\
\hline 2 & 5 & Oil bath, Reflux & water & 110 & 30 \\
\hline 3 & 10 & Oil bath, Reflux & water & 110 & 88 \\
\hline 4 & 15 & Oil bath, Reflux & water & 110 & 88 \\
\hline 6 & 20 & Oil bath, Reflux & water & 110 & 90 \\
\hline 7 & 25 & Oil bath, Reflux & water & 110 & 88 \\
\hline 8 & 30 & Oil bath, Reflux & water & 110 & 88 \\
\hline 9 & 10 & Oil bath, Reflux & $\mathrm{EtOH}$ & 110 & 65 \\
\hline 10 & 10 & Oil bath, Reflux & Aqueous EtOH (1:1) & 110 & 75 \\
\hline 11 & 10 & Oil bath, Reflux & $\mathrm{MeCN}$ & 110 & 55 \\
\hline 12 & 10 & Oil bath, $100^{\circ} \mathrm{C}$ & DMSO & 110 & 58 \\
\hline 13 & 10 & Oil bath, $100^{\circ} \mathrm{C}$ & THF & 110 & 56 \\
\hline 14 & 10 & Oil bath, $100^{\circ} \mathrm{C}$ & NIL & 110 & 40 \\
\hline
\end{tabular}

aReaction conditions: o-phenylenediamine (1.2 mmol), Benzil (1 mmol), blsolated yield

With this initial result, we have studied the catalytic system Dowex $50 \mathrm{~W}$ in water at refluxing condition with various $o$-aromaticdiamines 1 and 1,2-diketones 2 forming the desired substituted quinoxaline 3 derivatives and the outcome were depicted in Table 2. Electron pushing and pulling both group attached in aromatic ring of 1,2-diketones were investigated. Various electron donating and withdrawing groups attached to $o$-aromaticdiamines also examined. All the cases low reaction times and excellent yield of the products was observed.

Electron-pushing group at the aromatic ring of o-diamine favoured the development of products (Entries 8 and 9, Table 2) to provide better yields. Electron-pulling groups in contrast such as bromo, chloro and benzoyl afforded the desired products in slightly lower yields (80-84\%) (Entries10-12, Table 2). The reaction of aliphatic 1,2-diammine 1 with 1,2-diphenyldiketone $2 \mathrm{a}$ was also examined and obtained a moderate yield (78\%) of the desired product 3 even after running the reaction under refluxing condition for $3 \mathrm{~h}$ (Entry 15, Table 2). Reaction of 2,3diaminonaphthalene $1 \mathrm{~g}$ and 1,2-diphenyldiketone $2 \mathrm{a}$ also gave a low yield compared to others. In contrast, no significant change of product yield was observed when substituents present at the 1,2-diketones.

In summary, quinoxaline derivatives have been created in presence of promoter Dowex 50W in aqueous medium. This method has several advantages such as a very mild reaction conditions, short reaction times, easy workup and high yield of the products. Here Dowex $50 \mathrm{~W}$ acts as a reusable green catalyst because it can be easily separated from the reaction medium and reused for several reactions with no alteration of catalytic activity. For the production of quinoxaline derivatives in largescale this method will be helpful in near future.
The plausible mechanistic pathway is depicted in Scheme 2 to generate quinoxalines using 1,2-diketones and o-diamines. Since Dowex 50W is a proton source in aqueous medium so in the first step protonation takes place at the carbonyl oxygen atom which makes more electrophilicity of the o-phenylenediamines $1 \mathrm{a}$ and then quinoxaline derivatives $3 a$ were generated by the elimination of twice water molecules and details shown in the mechanism.

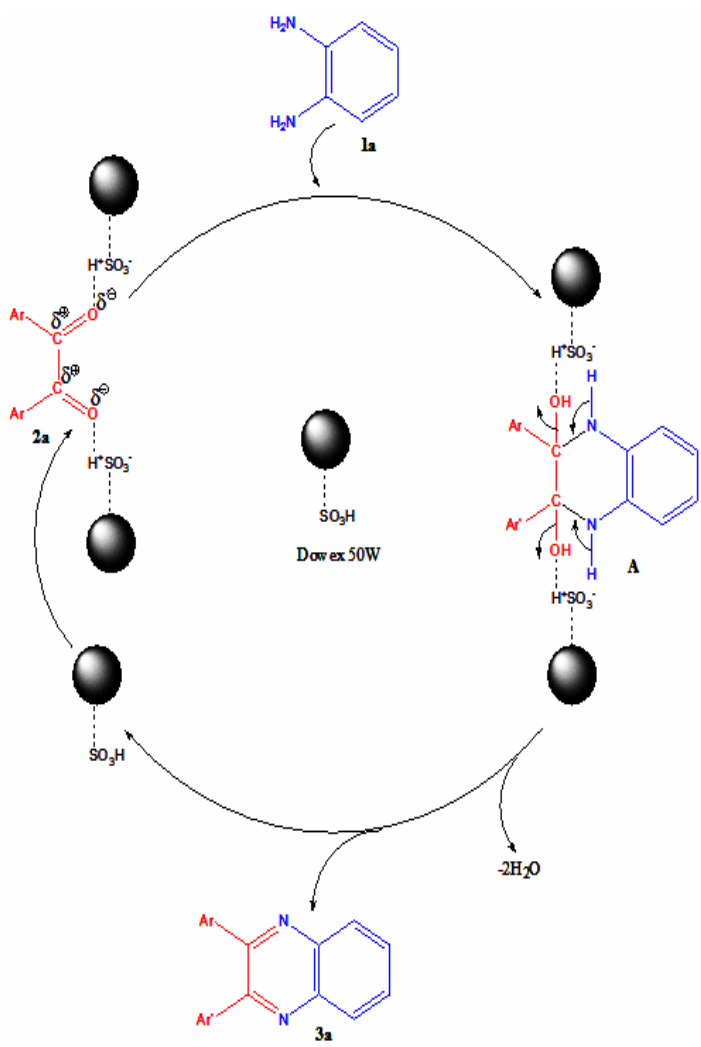

Scheme 2. Plausible mechanism for the production of quinoxaline derivatives 
Table 2: Synthesis of quinoxaline derivative

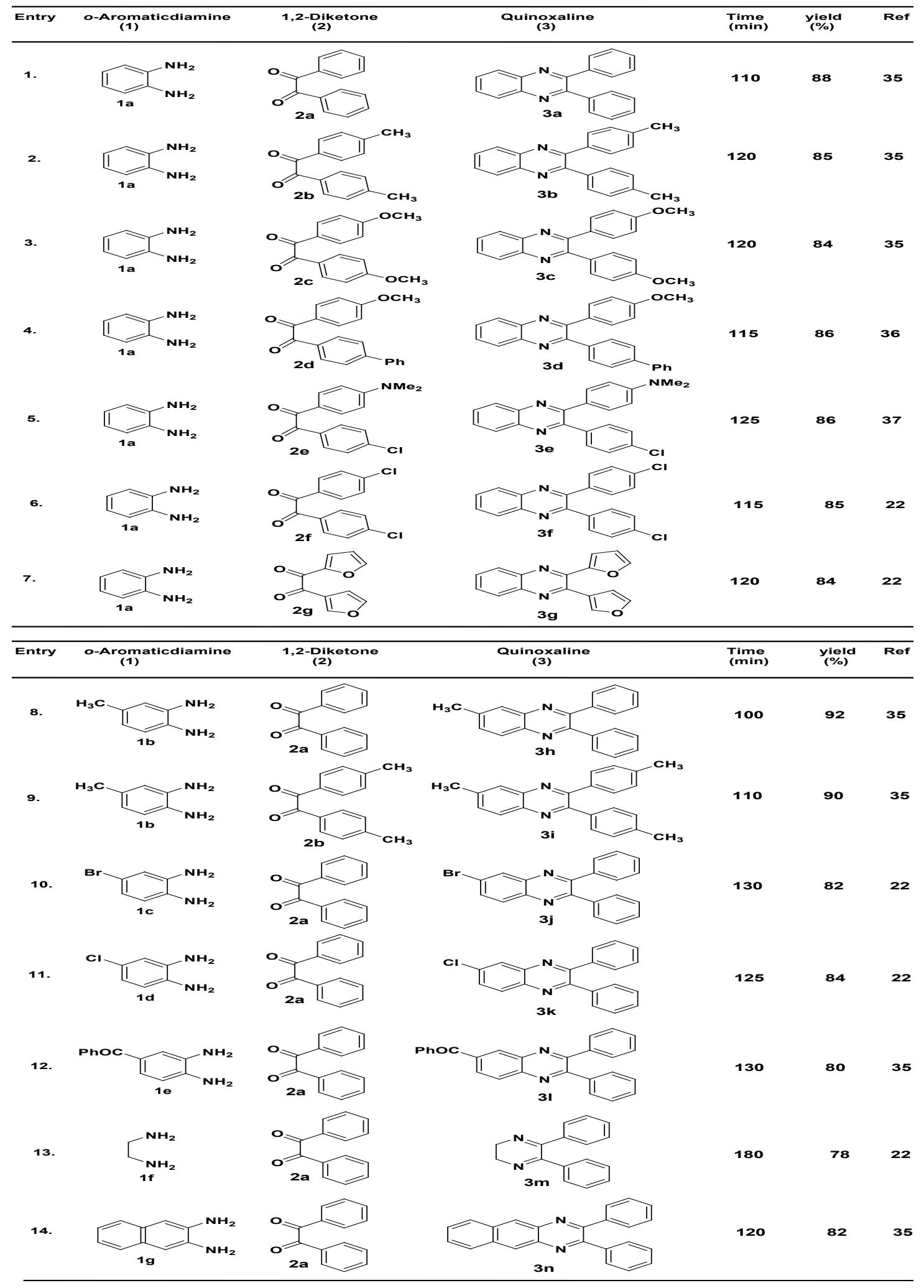




\section{EXPERIMENTAL}

Chemicals 0 -aromaticdiamine (1), 1,2diketones (2) and Dowex 50W in acid form were purchased from Spectrochem Pvt. Ltd. (Mumbai, India) and SRL, India. ${ }^{1} \mathrm{H}-\mathrm{NMR}$ and ${ }^{13} \mathrm{C}$-NMR spectra were recorded on a Bruker $300 \mathrm{MHz}$ spectrometer. From Aldrich chemical company NMR solvents $\mathrm{CDCl}_{3}$, DMSO- $d_{6}$ and TMS as the internal standard were purchased. Perkin Elmer Spectrophotometer was used to study FT-IR spectra. Thin layer chromatography was used to monitor the reaction. Electrical melting point apparatus were used to determine the melting point.

\section{General procedure}

1,2-diketones $(1.0 \mathrm{mmol}), o$-aromaticdiamines (1.2 mmol), $5 \mathrm{~mL}$ water and Dowex $50 \mathrm{~W}$ (10 mol\%) were taken in a $50 \mathrm{~mL}$ Erlenmeyer flask with a condenser and it was refluxed in an oil bath with a specific time period with stirring. The reaction was monitored by TLC time to time. After the complete conversion of the reaction indicated by brown spot in TLC then the crude product was cooled and diluted with $5 \mathrm{~mL}$ ethanol and Dowex $50 \mathrm{~W}$ was separated by filtration. Solution was concentrated and it was kept in the refrigerator for crystallization to prepare pure crystals of quinoxaline derivatives. ${ }^{1} \mathrm{H}$-NMR, ${ }^{13} \mathrm{C}$-NMR and FT-IR spectral data of all the known compounds (3a-n) were checked with the data of authentic known compounds.

\section{Selected characterization data for synthesized compounds \\ 2,3-Diphenylquinoxaline (3a) \\ White solid, M.P: $127^{\circ} \mathrm{C}$ [Lit.35 $128-129^{\circ} \mathrm{C}$ ],}

FT-IR (neat, $\mathrm{cm}^{-1}$ ): 3056, 1541, 1495, 1449, 1356, ${ }^{1} \mathrm{H}$ NMR $\left(300 \mathrm{MHz}, \mathrm{CDCl}_{3}\right): \delta: 7.32-7.37(\mathrm{~m}, 6 \mathrm{H})$, 7.56 (dd, 4H), 7.75 (dd, 2H), 8.2 (dd, 2H), ${ }^{13} \mathrm{CNMR}$ $\left(75 \mathrm{MHz}, \mathrm{CDCl}_{3}\right): \delta: 153.5,141.3,139.2,129.9$, 129.8, 129.3, 128.8, 128.3, Analytical calculation for $\mathrm{C}_{20} \mathrm{H}_{14} \mathrm{~N}_{2}(\%)$ : C: 85.08; $\mathrm{H}: 5.00 ; \mathrm{N}: 9.92$; Found: C: $85.00 ; \mathrm{H}: 4.90 ; \mathrm{N}: 9.82$.

\section{4-(2-(4-Chlorophenyl)quinoxalin-3-yl)-N,N- dimethylbenzenamine (3e)}

White solid, M.P: $170{ }^{\circ} \mathrm{C}$. [Lit.37 168-170 $\left.{ }^{\circ} \mathrm{C}\right]$, FT-IR (neat, $\left.\mathrm{cm}^{-1}\right): 3057,2932,1616,1542,1449$, 1354, ${ }^{1} \mathrm{H} \mathrm{NMR}\left(300 \mathrm{MHz}, \mathrm{CDCl}_{3}\right): 8: 3.01$ (s, 2Me, 6H), 6.68 (dd, 2H), 7.37 (dd, 2H), 7.45 (dd, 2H), 7.57 (dd, 2H), 7.70-7.75 (m, 2H), 8.11-8.14 (m, 2H), ${ }^{13} \mathrm{CNMR}$ $\left(75 \mathrm{MHz}, \mathrm{CDCl}_{3}\right): \delta: 153.3,152.2,150.9,141.6,140.6$, 138.6, 134.8, 131.1, 131.0, 129.9, 129.2, 129.1, 129.0, 128.6, 126.0, 111.8, 40.0, Analytical calculation for $\mathrm{C}_{22} \mathrm{H}_{18} \mathrm{CIN}_{3}(\%): \mathrm{C}: 73.43 ; \mathrm{H}: 5.04 ; \mathrm{N}: 11.68$; Found: C: $73.33 ; \mathrm{H}: 4.89 ; \mathrm{N}: 11.43$.

\section{6-Chloro-2,3-diphenylquinoxaline (3k)}

White solid, m.p: $125^{\circ} \mathrm{C}$. [Lit.35 124-125

${ }^{\circ} \mathrm{C}$ ], FT-IR (neat, $\mathrm{cm}^{-1}$ ): 3056, 1606, 1498, ${ }^{1} \mathrm{H}$ NMR $\left(300 \mathrm{MHz}, \mathrm{CDCl}_{3}\right): \delta: 8.19(\mathrm{~s}, 1 \mathrm{H}), 8.14(\mathrm{~d}, 1 \mathrm{H}), 7.74$ $(\mathrm{m}, 1 \mathrm{H}), 7.53(\mathrm{~d}, 4 \mathrm{H}), 7.40(\mathrm{~m}, 6 \mathrm{H}),{ }^{13} \mathrm{C}$ NMR $(75 \mathrm{MHz}$, $\left.\mathrm{CDCl}_{3}\right): \delta: 154.5,153.7,141.4,139.7,138.9,135.7$, 132.2, 131.0, 130.5, 130.0, 129.9, 129.8, 129.2, $129.1,128.8,128.1$, Analytical calculation for $\mathrm{C}_{20} \mathrm{H}_{13} \mathrm{CIN}_{2}$ (\%): C: 75.83; H: 4.14; N: 8.84; Found: C: $75.83 ; \mathrm{H}: 4.14 ; \mathrm{N}: 8.84$.

\section{CONCLUSION}

New high yielding Eco-friendly protocol has been developed for preparing various substituted quinoxaline derivatives using easily available, nontoxic and nonhazardous heterogeneous catalyst Dowex $50 \mathrm{~W}$ in aqueous medium. A series of quinoxaline derivatives were synthesized with various 1,2-diketones and different $o$-phenylenediamine under mild and green reaction condition with excellent yield. Green solvent, simple methodology and easy purification of wide variety of the isolated products are the main advantages of our process.

\section{ACKNOWLEDGEMENT}

$A D$ is very much grateful to his Ph.D. supervisor Prof. Chhanda Mukhopadhyay, Department of Chemistry, University of Calcutta for providing laboratory facility. Authors are thankful to the staff of the Department of Chemistry for their continuous support.

\section{Conflict of Interest}

No conflict of interest regarding this article

\section{REFERENCES}

1. Katritzky, A. R.; Rees, C.W.; Comprehensive Heterocyclic Chemistry, Pergamon: Oxford, Part 2B., 1984, 3, 157.

2. Sherman, D.; Kawakami, J.; He, H. Y.;
Dhun, F.; Rios, R.; Liu, H.; Pan, W.; Xu, Y. J.; Hong, S. P.; Arbour, M.; Labelle M.; Duncton, M. A. J.; Tetrahedron Lett., 2007, 48, 8943. 
3. (a) Seitz, L. E.; Suling, W. J.; Reynolds, R. C.; J. Med. Chem., 2002, 45, 5604-5606. (b) Hui, X.; Desrivot, J.; Bories, C.; Loiseau, P. M.; Franck, X.; Hocquemiller, R.; Figadere, B.; Bioorg. Med. Chem. Lett., 2006, 16, 815-820. (c) YB, K.; YH, K.; JY, P.; SK, K.; Bioorg. Med. Chem. Lett., 2004, 14, 541-544. (d) Loriga, M.; Piras, S.; Sanna, P.; Paglietti, G. Farmaco., 1997, 52, 157-166. (e) Lindsley, C. W.; Zhao, Z.; Leister, W. H.; Robinson, R. G.; Barnett, S. F.; Defeo-Jones, D.; Jones, R. E.; Hartman, G. D.; Huff, J. R.; Huber, H. E.; Duggan, M. E.; Bioorg. Med. Chem. Lett., 2005, 15, 761-764. (f) Sarges, R.; Howard, H. R.; Browne, R. G.; Lebel, L. A.; Seymour, P. A.; Koe, B. K.; J. Med. Chem., 1990, 33, 2240-2254. (g) Srinivas, C.; Kumar, C. N. S. S. P.; Rao, V. J.; Palaniappan, S.; J. Mol. Catal. A: Chem., 2007, 265, 227230. (h) Ghomsi, N. T.; Ahabchane, N. E. H.; Es-Safi, N. E.; Garrigues, B.; Essassi, E. M.; Spectroscopy Lett., 2007, 40, 741-751. (j) Hui, X.; Desrivot, J.; Bories, C.; Loiseau, P. M.; Franck, X.; Hocquemiller, R.; Figadere, B.; Bioorg. Med. Chem. Lett., 2006, 16, 815.

4. Sakata, G.; Makino, K.; Karasawa, Y.; Heterocycles., 1988, 27, 2481-2515.

5. (a) Kumar, A.; Kumar, S.; Saxena, A.; De, A.; Mozumdar, S.; Catal. Commun., 2008, 9, 778-784. (b) Jaung, J.Y.; Dyes and Pigments., 2006, 71, 45.

6. Dailey, S.; Feast, W. J.; Peace, R. J.; Sage, I. C.; Till, S.; Wood, E L.; J. Mater. Chem., 2001, 11, 2238-2243.

7. Thomas, K. R. J.; Velusamy, M.; Lin, J. T.; Chuen, C. H.; Tao, Y. T.; Chem. Mater., 2005, 17, 1860-1866.

8. Crossley, M. J.; Johnston, L. A.; Chem. Commun., 2002, 1122.

9. Kazunobu, T.; Ryusuke, O.; Tomohiro, M.; Chem. Commun., 2002, 212-219.

10. (a) Dell, A.; William, D. H.; Morris, H. R.; Smith, G. A.; Feeney, J.; Roberts, G. C. K.; J. Am. Chem. Soc., 1975, 97, 2497-2502. (b) Heravi, M. M.; Bakhtiari, K.; Tehrani, M. H.; Javadi, N. M.; Oskooie, H. A.; Arkivoc., 2006, (xvi), 1622. (c) Raw, S. A.; Wilfred, C. D.; Taylor, R. J. K.; Chem. Commun., 2003, 18, 2286.
11. (a) Woo, G. H. C.; Snyder, J. K.; Wan, Z. K.; Prog. Heterocycl. Chem., 2002, 14, 279. (b) Roy, P.; Ghorai, B. K.; Beilstein. J. Org. Chem., 2010, 6, 52.

12. Antoniotti, S.; Donach, E.; Tetrahedron Lett., 2002, 43, 3971-3973.

13. Wu, Z.; Ede, N. J.; Tetrahedron Lett., 2001, 42, 8115-8118.

14. (a) Zhao, Z.; Wisnoski, D. D.; Wolkenberg, S. E.; Leister, W. H.;Wang, Y.; Lindsley, C. W.; Tetrahedron Lett., 2004, 45, 4873-4876. (b) Gris, J.; Glisoni, R.; Fabian, L.; Fernández, B.; Moglioni,A. G.; Tetrahedron Lett., 2008, 49, 10531056. (c) Mohsenzadeh, F.; Aghapoor, K.; Darabi, H. R.; J. Braz. Chem. Soc., 2007, 18, 297.

15. Raw, S. A.; Wilfred, C. D.; Taylor, R. J. K.; Org. Biomol. Chem., 2004, 2, 788-796.

16. Bhosale, R. S.; Sarda, S. R.; Ardhapure, S. S.; Jadhav, W. N.; Bhusare, S. R.; Pawar, R. P.; Tetrahedron Lett., 2005, 46, 7183-7186.

17. More, S. V.; Sastry, M. N. V.; Yao, C. F.; Green Chem., 2006, 8, 91-95.

18. Huang, T.K.;Wang, R.; Shi, L.; Lu, X. X.; Catal. Commun., 2008, 9, 1143-1147.

19. (a) Fang, D.; Gong, K.; Fei, Z.; Zhou, X.; Liu, Z.; Catal. Commun., 2008, 9, 317-320. (b) Potewar, T. M.; Ingale, S. A.; Srinivasan, K. V.; Synth. Commun., 2008, 38, 3601.

20. Shaabani, A.; Maleki, A.; Chin. J. Chem., 2007, 25, 818-821.

21. Kumar, A.; Kumar, S.; Saxena, A.; De, A.; Mozumdar, S.; Catal. Commun., 2008, 9, 778-784.

22. Cai, J. J.; Zou, J. P.; Pan, X. Q.; Zhang, W.; Tetrahedron Lett., 2008, 49, 7386-7390.

23. Brown, D.J.; Taylor, E.C.;Wipf, P.; "Quinoxalines," in The Chemistry of Heterocyclic Compounds: John Wiley \& Sons, Hoboken, N. J. USA., Eds., 2004, 61, 1-510.

24. Jafarpour, M.; Rezaeifard, A.; Danehchin, M.; Applied Catalysis A: General., 2011, 394, 48-51.

25. Antoniotti, S.; Dunach, E.; Tetrahedron Lett., 2002, 43, 3971-3973.

26. Xekoukoulotakis, N. P.; HadjiantoniouMaroulis, C. P.; Maroulis, A. J. Tetrahedron Lett., 2000, 41, 10299-10302. 
27. Raw, S. A.; Wilfred, C. D.; Taylor, R. J. K.; Org. Biomol. Chem., 2004, 2, 788-796.

28. More, S. V.; Sastry, M. N. V.; Wang, C. C.; ChingFa, Y.; Tetrahedron Lett., 2005, 46, 6345-6348.

29. Xie, C.; Zhang, Z.; Li, D.; Gong, J.; Han, X.; Liu, X.; Ma, C.; J. Org. Chem., 2017, 82, 3491-3499.

30. Sadjadi, S.; Sadjadi, S.; Hekmatshoar, R.; Ultrason Sonochem., 2010, 17, 764-767.

31. Zhou, J. F.; Gong, G. X.; Shi, K. B.; Zhi, S.; J. Chinese Chem. Lett., 2009, 20, 672-675.

32. (a) Krishnakumar, B.; Velmurugan, R.; Jothivel, S.; Swaminathan, M.; Catal. Commun., 2010, 11, 997-1002. (b) Darabi, H. R.; Mohandessi, S.; Aghapoor, K.; Mohsenzadeh, F.; Catal. Commun., 2007, 8, 389-392.

33. Niknam, K.; Saberi, D.; Mohagheghnejad, M.; Molecules., 2009, 14, 1915-1926.

34. (a) Mukhopadhyay, C.; Datta, A.; Banik,
B. K.; Heterocycles., 2007, 71, 181-188. (b) Mukhopadhyay, C.; Tapaswi, P. K.; Tetrahedron Lett., 2008, 49, 6237-6240. (c) Makhopadhyay, C.; Datta, A.; J. Het. Chem., 2009, 46, 91-95.

35. (a) Steven, A. R.; Cecilia, D. W.; Richard, J. K. T.; Chem. Commun., 2003, 2286. (b) Bhosale, R. S.; Sarda, S. R.; Ardhapure, S. S.; Jadhav, W. N.; Bhusare, S. R.; Pawar, R. P.; Tetrahedron Lett., 2005, 46, 7183-7186. (c) More, S. V.; Sastry, M. N. V.; Wang, C. C.; Yao, C. F.; Tetrahedron Lett., 2005, 46, 6345-6348.

36. Mao, L.; Sakurai, H.; Hirao, T.; Synthesis., 2004, 2535-2539.

37. Islami, M. R.; Hassani, Z.; Arkivoc., 2008, (xv), 280-287.

38. Akkilagunta, V. K.; Reddy, V.P.; Kakulapati, R. R.; Synlett., 2010, 2571-2574. 